\title{
BETWEEN-SEASON ATTRACTION OF COTTON BOLL WEEVIL, Anthonomus grandis Boh. (Coleoptera: Curculionidae) ADULTS BY ITS AGGREGATION PHEROMONE
}

\author{
Wedson Desidério Fernandes ${ }^{1}$; Sérgio Luis de Carvalho²; Mohamed Habib ${ }^{3 *}$ \\ ${ }^{1}$ Depto. Ciências Biológicas - Univ. Federal de Mato Grosso do Sul - CEP: 79825-070 - Dourados, MS. \\ ${ }^{2}$ Depto. Biologia Aplicada à Agricultura - UNESP - CEP: 15378-000 - Ilha Solteira, SP. \\ ${ }^{3}$ Depto. Zoologia - Instituto de Biologia - UNICAMP - CEP: 13083-970 - Campinas, SP. \\ ${ }^{*}$ Corresponding author <mohamed@reitoria.unicamp.br >
}

\begin{abstract}
The present study was undertaken to investigate the attractiveness of boll weevil adults by its aggregation pheromone under winter field conditions. Two experimental fields were utilized at "Casa Branca", $\mathrm{SP}$, Brazil. For each one, three areas were established near the refuge vegetation, sparated $500 \mathrm{~m}$ from each other. Each area was divided in three sub-areas or blocks of $100 \mathrm{~m}^{2}$ to receive pheromone applications $(2.5 \mathrm{~g}$ per block). In addition to the pre-application counting, five additional evaluations were carried out after the pheromone applicaton. Ten randomized sampling points per block were considered in each evaluation process. $A$. grandis adults responded immediately to the pheromone applications, and were captured for 14 days . The highest level of attractiveness was observed 24 hours after application. The application of the boll weevil aggregation pheromone during winter could increase the predation by natural enemies, due to the increase of prey availability. Chemical control can be recommended 24 hours after pheromone applications in small plots as a between-season strategy for the suppression of boll weevil adults.

Key words: Anthonomus grandis, Insecta, cotton, management
\end{abstract}

\section{ATRAÇÃo DE ADULTOS DO BICUDO DO ALGODOEIRO, Anthonomus Grandis Boh. (Coleoptera: Curculionidae) POR SEU FEROMÔNIO DE AGREGAÇÃO NA ENTRESSAFRA}

\begin{abstract}
RESUMO: O presente estudo teve como objetivo investigar a atratividade do bicudo do algodoeiro ao seu feromônio de agregação em período de inverno. Foram utilizados dois campos experimentais no município de Casa Branca, SP. Em cada um destes, foram estabelecidas três áreas separadas de aproximadamente 500 metros, sempre próximas à vegetação de refúgio. Cada área foi dividida em três sub-áreas ou blocos de $100 \mathrm{~m}^{2}$ para receber a aplicação do feromônio (2,5 g por bloco). Foi realizada uma contagem de bicudos adultos no solo antes, e mais cinco após a aplicação de feromônio. Em cada bloco, foram observadas dez parcelas aleatórias, para a avaliação dos bicudos. Os adultos de $A$. grandis foram atraídos imediatamente após a aplicação do feromônio, sendo capturados por mais de 14 dias após. O índice mais elevado de atração foi observado 24 horas após a aplicação. A utilização do feromônio de agregação durante o inverno, pode aumentar a ação reguladora exercida pelos inimigos naturais, devido ao aumento de disponibilidade de presas. Controle químico pode ser recomendado 24 horas após a aplicação de feromônio em pequenas parcelas, como uma estratégia para a supressão de adultos de Anthonomus grandis em período de entressafra.
\end{abstract}

Palavras-chave: Anthonomus grandis Insecta, algodão, manejo, entressafra

\section{INTRODUCTION}

The cotton boll weevil (BW), Anthonomus grandis Boheman, was detected in the São Paulo State, Brazil, for the first time in 1983 (Habib \& Fernandes, 1983), and at the present time it is considered as one of the most important key-pests in Brazilian cotton fields. Many investigations were undertaken to study the population behavior, biological responses and other ecological aspects of this curculionid pest in this new habitat, to establish IPM strategies for its control (Fuchs \& England, 1989; Gutierrez et al., 1991; Gabriel et al., 1992; Pierozzi Jr. \& Habib, 1992a, 1992b, 1993a, 1993b; Ramalho \& Silva, 1993; Fernandes et al., 1994; 1996; Araujo \&
Azevedo, 1997). Many ecological and behavioral differences were observed among boll weevil populations in their new environment in comparison to other cotton agroecosystems, mainly of the U.S.A. (Pierozzi Jr., 1989).

Among several types of insect adaptations to environmental changes, some serve as protection against the seasonal climatic changes. Periodic migrations, diapause or dormancy are some of such adaptations. Regarding adults of the cotton boll weevil, since Brazzel Jr. \& Newson (1959) described and characterized the diapause process, many other scientists have studied these adaptation mechanisms and their role in population dynamics. The spark of the diapause process seems to be associated to the limited availability of square buds 
for the BW, low temperatures and plant exposition to short day length (Pierozzi Jr., 1989). The utilization of fruits (bolls) for larval boll weevil feeding is also considered as an important factor inducing diapause (Lloyd et al., 1967; Lloyd, 1986). Diapause, as well as dispersion, can be caused by some chemicals present in such fruits. According to Arellano (1995), the decrease in the amount of cotton squares and increase of boll availability can be considered as indicators of the winter period proximity and, consequently, the activation of the preparatory metabolism in the insect population. Increase of some metabolic rates, accumulation of fat tissues and drastic reduction of sexual and reproductive activities are some of the observed responses.

A facultative diapause occurs among adults of this curculionid pest. In the USA diapause is a survival mechanism of such a pest between the cotton seasons. This behavior occurs when the cotton season is completed, and especially when soil moisture decreases inducing a plant stress. This phenomenon is observed in Mexican strains as much as the US southwestern ones. In agreement with Pierozzi Jr. \& Habib (1992a) we also believe that the boll weevils found in Brazil are of the same strain which occurs in Mexico and southwestern USA. According to Cross (1973), after the migration process, the diapausing weevils, and apparently some nondiapausing ones, dispersed into the forest litter for hibernation, and this type of dispersion occurs in regions with wet and cold between-season conditions. In other regions with dry and hot conditions during this period, dispersion would normally occur in order to localize an alternative host. Finally, some weevils would survive in old cotton stalks. Some authors consider the possibility that a part of $A$. grandis population does not accomplish the diapause process (Palmer \& Cate 1992; Fernandes et al., 1994).

While BW growth and reproduction are not so common during overwinter seasons of temperate zones, and the diapause is vital for their populations; in the tropics the climatic conditions, including temperature and photoperiodism, are not sufficient to trigger this process. Moreover several host plants can stay available during the whole year offering pollens to feed adults (Tauber et al., 1986; Brown \& Phillips Jr., 1989; Benedict et al., 1991; Chandler \& Wright, 1991; Jones et al., 1992). Habib et al. (1984) captured great amounts of $A$. grandis adults in grandlure pheromone traps during winter.

In the Paraná State, southern Brazil, the presence of $A$. grandis as a key pest increased the cotton production costs during the last five years due to the number of insecticide applications which increased from an average of 5.4 to 10.1 applications per season (Morales et al., 1997). According to MafraNeto \& Bakers (1996), two methods are used to prevent mating, using synthetic pheromones: "mating disruption" and "attract-and-kill". In the second method, pheromone sources are mixed with small amounts of insecticides that poison the males and females attracted by the pheromone.

The present study was conducted to investigate the attractiveness of $A$. grandis adults to the aggregating pheromone (grandlure), under winter field conditions, in southwestern Brazil.

\section{MATERIAL AND METHODS}

Attractiveness bioassays were carried out during two consecutive between-season periods, at Casa Branca Municipality, SP, southeastern Brazil. For the first period, the study was undertaken in a cotton field (400 ha area, submitted to an IPM program), surrounded by soybean, corn and chrysanthemum fields in addition to a small secondary natural forest. For the second period, a 70 ha area also subjected to the same IPM program and surrounded by corn, sugar cane and orchard areas, was used. In both situations, the IPM program included the utilization of vegetable traps formed by cotton plants cultivated a month before on the boundary rows of the farm, which corresponded to about $5 \%$ of the total area. The cotton plant stalks were cut and eliminated as soon as the cotton was harvested, but after three months some sprouts could be observed in all area.

For each between-season period, three areas (A1, A2 and A3 with $500 \mathrm{~m}$ distance between each other) were established, near natural refuge vegetation or orchard areas, to study the pheromone attractiveness. Each area was divided in three separate blocks $\left(100 \mathrm{~m}^{2}\right.$ each), $10 \mathrm{~m}$ apart from each other, and the first of them was $20 \mathrm{~m}$ away from the edge of the refuge area (Figure 1).

For each block, 10 randomized sampling points $\left(1 \mathrm{~m}^{2}\right.$ each) were established for counting of the attracted boll weevil adults. One pre-application and five postapplication counting (2 hours, 1, 7, 14 and 21 days) were carried out. In each block area, $2.5 \mathrm{~g}$ of grandlure pheromone (Blockaide ${ }^{\mathrm{TM}}$ ) were homogeneously distributed. Sites where BW adults were observed in each block (if flying, on the ground, on weeds or on cotton sprouts) were also observed. Statistical analysis was carried out with transformed data in $\sqrt{X+0.5}$, subjected to analysis of variance and Duncan's multiple range test.

\section{RESULTS AND DISCUSSION}

Before the "grandlure" application boll weevil adults were concentrated mainly in the refuge areas, in both periods of study. During the pre-application counting, no adults were found in the nine blocks of the first between-season period, while only two adults were encountered in the nine blocks of the second period. The little amount of sprouts, present in the bioassay area, were not enough to attract the over-wintering boll weevil 


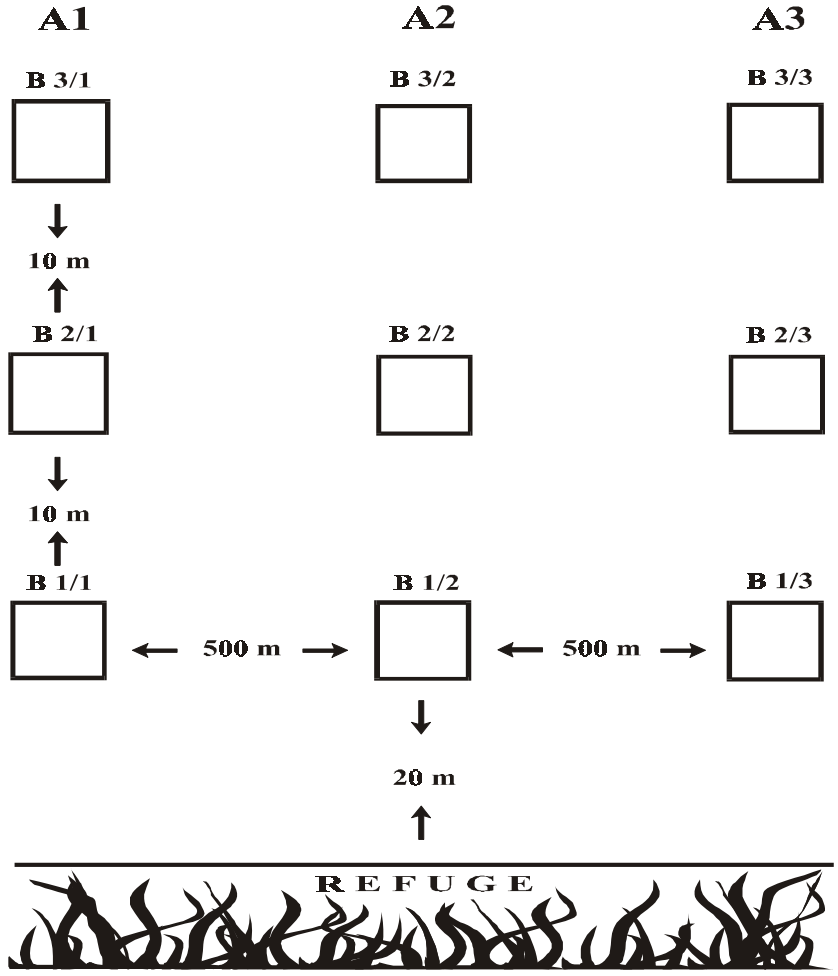

Figure 1 - Distribution scheme of areas and blocks in relation to the natural refuges.

adults. However, as shown in TABLE 1, they began to be attracted as soon as the pheromone was applied. The highest attraction was observed 24 hours after grandlure application in both between-season periods. Such attractiveness can be explained by the highest pheromone release and consequently the highest boll weevil response at the first days after release. Habib et al. (1984) studying the aggregating attractiveness of Blockaide $^{\mathrm{TM}}$, detected a gradual attraction increase up to the sixth day.

The attracted weevils moved initially to sprouts and buds, and fed on them intensively. Authors observed up to nine adults in an only bud square; and in several occasions adults were observed in copulation.

A part of the boll weevil population was found to be feeding on weed pollen. However, the longer the time after pheromone application, the smaller the population on weeds or/and ground, thus concentrating on cotton sprouts and buds (TABLES 2 and 3 ).

Pheromone attractive quality and insect behavior were also studied among other coleopteran species in relation to their aggregation pheromones (Roelofs, 1981; Lloyd et al., 1981). According to Tumlinson et al. (1969) and White \& Rummel (1978), the males are the first individuals to be attracted to the kairomone produced by the cotton plants. These attracted males start feeding and immediately produce and liberate their aggregation pheromone, attracting consequently the adult females. Such a behavior could be studied in a future investigation with $A$. grandis adults. Kairomone is a substance produced or acquired by an organism that, when it
TABLE 1 - Total number and mean ( \pm SE) of cotton boll weevil adults per sampling point before and after pheromone applications.

\begin{tabular}{|c|c|c|c|}
\hline \multirow[b]{3}{*}{ Counting } & \multicolumn{2}{|r|}{$1^{\text {st }}$ PERIOD } & $2^{\text {nd }}$ PERIOD \\
\hline & \multicolumn{2}{|c|}{ Number of adults } & Number of adults \\
\hline & Total & $\begin{array}{c}\text { Mean/sampling } \\
\text { point }\end{array}$ & $\begin{array}{c}\text { Total Mean/sampling } \\
\text { point }\end{array}$ \\
\hline Pre-aplication & 00 & 00 & $020.02 \pm 0.38$ A \\
\hline 2 hours after & 19 & $0.20 \pm 0.78 a b$ & $810.90 \pm 1.52 \mathrm{~B}$ \\
\hline 24 hours after & 75 & $0.83 \pm 1.64 b$ & $1361.51 \pm 1.61 \mathrm{C}$ \\
\hline 7 days after & 11 & $0.12 \pm 0.77 a b$ & $240.27 \pm 0.77 \mathrm{AB}$ \\
\hline 14 days after & 00 & 00 & $160.17 \pm 0.82 \quad A$ \\
\hline 21 days after & 00 & 00 & $090.10 \pm 0.74 \quad A$ \\
\hline
\end{tabular}

TABLE 2 - Total and percentage of boll weevils found on sprouts, weeds and/or on ground before and after pheromone application, during the first period.

\begin{tabular}{cccccccc}
\hline \multicolumn{7}{c}{ NUMBER OF ADULTS } \\
\hline \multirow{2}{*}{ Phase } & $\begin{array}{c}\text { On cotton } \\
\text { sprouts }\end{array}$ & \multicolumn{2}{c}{ On weeds } & \multicolumn{2}{c}{ On ground } \\
\cline { 2 - 8 } & Total & $\%$ & Total & $\%$ & Total & $\%$ \\
\hline Pre-aplic. & 0 & 0 & 0 & 0 & 0 & 0 \\
2 h after & 11 & 57.89 & 4 & 21.05 & 4 & 21.05 \\
24 h after & 54 & 72.00 & 7 & 9.33 & 14 & 18.67 \\
7 d after & 7 & 63.64 & 2 & 18.18 & 2 & 18.18 \\
14 d after & 0 & 0 & 0 & 0 & 0 & 0 \\
21 d after & 0 & 0 & 0 & 0 & 0 & 0 \\
\hline
\end{tabular}

TABLE 3 - Total and percentage of boll weevils found on sprouts, weeds and/or on ground before and after pheromone application, during the second period.

\begin{tabular}{cccccccc}
\hline \multicolumn{7}{c}{ NUMBER OF ADULTS } \\
\hline Phase & \multicolumn{2}{c}{$\begin{array}{c}\text { On cotton } \\
\text { sprouts }\end{array}$} & \multicolumn{2}{c}{ On weeds } & \multicolumn{2}{c}{ On ground } \\
\cline { 2 - 8 } & Total & $\%$ & Total & $\%$ & Total & $\%$ \\
\hline Pre-aplic. & 2 & 100 & 0 & 0 & 0 & 0 \\
\hline 2 h after & 43 & 53.09 & 36 & 44.44 & 2 & 2.47 \\
\hline 24 h after & 97 & 71.32 & 37 & 27.21 & 2 & 1.47 \\
\hline 7 d after & 3 & 12.5 & 1 & 4.17 & 20 & 83.33 \\
\hline 14 d after & 16 & 100 & 0 & 0 & 0 & 0 \\
\hline $21 \mathrm{~d}$ after & 9 & 100 & 0 & 0 & 0 & 0 \\
\hline
\end{tabular}


reaches an individual of another species, evokes in the receiver a behavioral or a physiological reaction that is adaptively favorable to it, but not to the emitter (Nordlund, 1981).

Cotton kairomones, during the growing season, attract boll weevils; but small sprout rates during an overwinter period, are not sufficient to attract a significant number of $A$. grandis adults from surrounded areas, as shown in the present work. For this reason, it was very evident that the applied pheromone, in such a situation, was successfully able to attract a great number of active boll weevil adults from refuge areas within few hours after "grandlure" application.

The total absence of boll weevil adults, observed 14 and 21 days after pheromone application in the first period, showed the drastic effect of rain, reducing the pheromone attractiveness. On the other hand, during the second period, under no raining conditions, the high attractive capacity the extended up to 21 days.

Higher boll weevil presence in blocks nearest to the contiguous areas (block 1) was also observed. Those weevils were firstly attracted to blocks near to the refuge and then they pass to other blocks. However, no significant differences were observed between the number of adults found in those blocks during the two observation periods (TABLES 4 and 5). Moreover, it was observed that the amount of $2.5 \mathrm{~g}$ of grandlure $/ 100 \mathrm{~m}^{2}$ showed to be economic and sufficient to result in a good attractiveness.

Summy et al. (1993) under USA cotton field conditions, observed $A$. grandis adults to be attracted to pheromone traps nearest to cotton plants residues during between-season periods. Gabriel et al. (1992) in Brazil, found a reduced number of active BW on soil, during winter in areas near cotton fields. Habib et al. (1984) and Fernandes (1995) utilizing grandlure pheromone traps captured great amounts of BW in winter season.

The present authors believe that applications of the boll weevil pheromone during winter, could increase the predatory action by natural enemies, due to the increase of prey availability. The performance of predator ants like Solenopsis, Pheidole and others, can promote a population decrease of boll weevil adults. Fernandes et al. (1994) observed that the potential benefit of ants, removing over-wintering $A$. grandis adults on the ground, during the inter-cropping season, is mainly that of reducing the risk of high level infestation during the subsequent cotton growing cycle.

In spite of the extensive bibliography regarding the diapause of BW in United States and Mexico (Brazzel \& Newson, 1959; Mitchel et al., 1973) and few studies in Brazil (Campanhola et al., 1986, Campanhola \& Martin, 1987 ) it seems clear to the authors that, a high proportion of BW adults remains active under field conditions of southeastern Brazil, if cotton buds or alternative hosts plants, in adjacent areas, were available. Even those individuals with apparently diapause indicators, as atrophied reproductive organs, fat accumulation and
TABLE 4 - Mean ( \pm SE) of Boll Weevils found in three blocks at the first observation period before and after pheromone application.

\begin{tabular}{cccc}
\hline \multicolumn{4}{c}{ Boll We evils founded } \\
\hline & Block 1 & Block 2 & Block 3 \\
\cline { 2 - 4 } Counting & Mean \pm SE & Mean \pm SE & Mean \pm SE \\
\hline Pre-aplic. & $0.00 \pm 0.00$ & $0.00 \pm 0.00$ & $0.00 \pm 0.00$ \\
\hline 2h after & $1.33 \pm 0.76$ & $3.33 \pm 1.44$ & $1.67 \pm 0.76$ \\
\hline $24 \mathrm{~h}$ after & $5.33 \pm 2.75$ & $13.67 \pm 4.11$ & $6.00 \pm 2.46$ \\
\hline 7 d after & $0.33 \pm 0.76$ & $1.00 \pm 1.00$ & $2.33 \pm 1.51$ \\
\hline $14 \mathrm{~d}$ after & $0.00 \pm 0.00$ & $0.00 \pm 0.00$ & $0.00 \pm 0.00$ \\
\hline $21 \mathrm{~d}$ after & $0.00 \pm 0.00$ & $0.00 \pm 0.00$ & $0.00 \pm 0.00$ \\
\hline
\end{tabular}

Difference between three blocks were not significant. $F=0,260$ $P>0,01$, ANOVA test). Means transformed by $\sqrt{X+0.5}$.

TABLE 5 - Mean $( \pm$ SE) of Boll Weevils found in three blocks at the second observation period before and after pheromone application.

\begin{tabular}{crrc}
\hline \multicolumn{4}{c}{ Boll Weevil founded } \\
\hline & Block 1 & \multicolumn{1}{c}{ Block 2 } & Block 3 \\
\cline { 2 - 4 } Counting & Mean \pm SE & Mean \pm SE & Mean \pm SE \\
\hline Pre-aplic. & $0.67 \pm 0.76$ & $0.00 \pm 0.00$ & $0.00 \pm 0.00$ \\
\hline 2h after & $13.67 \pm 2.65$ & $5.33 \pm 1.79$ & $8.00 \pm 3.08$ \\
\hline 24 h after & $21.67 \pm 3.55$ & $17.00 \pm 4.36$ & $6.67 \pm 1.23$ \\
\hline 7 d after & $4.67 \pm 1.07$ & $2.33 \pm 0.76$ & $1.00 \pm 0.00$ \\
\hline 14 d after & $1.33 \pm 1.51$ & $2.67 \pm 1.51$ & $1.33 \pm 1.23$ \\
\hline 21 d after & $1.67 \pm 1.70$ & $0.33 \pm 0.76$ & $1.00 \pm 1.00$ \\
\hline
\end{tabular}

Difference between three blocks were not significant. $F=0,585$ $P>0,01$, ANOVA test). Means transformed by $\sqrt{X+0.5}$.

decrease of some metabolic activities, were observed to be only in a quiescent phase, but not in diapause, in agreement with Pierozzi Jr. \& Habib (1993b). According to Tauber et al. (1986) quiescence is a reversible state of suppressed metabolism imposed by environmental conditions such as temperature, humidity and unfavorable nutrition. Guerra et al. (1984), studying boll weevils in tropical areas in south of Mexico, observed quiescent forms and not a real diapause. Similar observations were made by Brazzel \& Newson (1959), who detected reproductive activities among the BW adults, during intercropping season.

Finally, it could be said that, at the end of the cotton season, the boll weevil adults disperse looking for alternative host plants, reproductive resources and refuge vegetations to spend the between-season period. Studies related with the permanence of boll weevils in refuge 
areas on alternative host plants were carried out by Campanhola et al. (1986), Lukefahr et al. (1986), Brown \& Phillips Jr. (1989) and Pierozzi Jr. \& Habib (1993b).

The attraction of adults of $A$. grandis to the aggregation pheromone Grandlureä, in small areas, according to the results of the present research, could be considered as a benefit IPM strategy during winter. Chemical insecticide treatments in these trap blocks (attract and kill), could be recommended 24 hours after pheromone application, as a between-season control method to suppress $A$. grandis adults. This practice, certainly, would reduce the number of chemical insecticide applications and, consequently, the cost of the control of such a pest, during the growing season.

\section{ACKNOWLEDGMENTS}

To Prof. Odival Faccenda for the assistance in the statistical analyses.

\section{REFERENCES}

ARAUJO, L.H.A.; AZEVEDO, F.R. Aspectos biológicos de Catolaccus grandis (Burks) (Hymenoptera: Pteromalidae), parasitóide do bicudo do algodoeiro. Anais da Sociedade Entomológica do Brasil, v.26, p.503-506, 1997.

ARELLANO, M. Parâmetros fisiológicos do bicudo do algodoeiro, Anthonomus grandis Boheman (Coleoptera: Curculionidae), durante o ciclo da planta e após a colheita do algodão. Campinas, 1995. Tese (Doutorado) - Instituto de Biologia, Universidade Estadual de Campinas.

BENEDICT, J.H.; WOLFENBARGER, D.A.; BRYANT JR., V.M.; GEORGE, D.M. Pollens ingested by boll weevils (Coleoptera: Curculionidae) in Southern Texas and Northeastern Mexico. Journal of Economic Entomology, v.84, p.126-131, 1991

BRAZZEL JR., J.R.; NEWSON, L.D. Diapause in Anthonomus grandis Boh. Journal of Economic Entomology, v.52, p.603-611, 1959.

BROWN, C.M.; PHILLIPS JR., S.A. Weeping love-grass as an overwintering habitat for the boll weevil (Coleoptera: Curculionidae). Journal of Economic Entomology, v.82, p.799-802, 1989

CAMPANHOLA, C.; MARTIN, D.F.; MELO, A.P.; MELO, A.S. Observação de diapausa em adultos do bicudo do algodoeiro (Anthonomus grandis Boheman, 1843) (Coleoptera, Curculionidae) no Estado de São Paulo. Anais da Sociedade Entomológica do Brasil, v.15, p.99-108, 1986.

CAMPANHOLA, C.; MARTIN, D.F. Observação de adultos de bicudo em hibernação. Campina Grande: EMBRAPA, CNPA, 1987. 3p. (Comunicado Técnico, 1).

CHANDLER, L.D.; WRIGHT, J.E. Longevity of the boll weevil (Coleoptera: Curculionidae) on cotton and alternate feeding sources under various temperature regimes in the laboratory. Journal of Economic Entomology, v.84, p.1699-1704, 1991.

CROSS, W. H. Biology, control and eradication of the boll weevil. Annual Review of Entomology, v.18, p.17-46, 1973.

FERNANDES, W.D. Estudos Populacionais sobre Anthonomus grandis Boheman, 1843 (Coleoptera: Curculionidae) e sua interação com Gossypium hirsutum L. (Malvaceae: Gossypiae). Campinas, 1995. Tese (Doutorado) - Instituto de Biologia, Universidade Estadual de Campinas.
FERNANDES, W.D.; OLIVEIRA, P.S.; CARVALHO, S.L.; HABIB M.E.M. Pheidole ants as potential biological control agents of the boll weevil, Anthonomus grandis (Col., Curculionidae), in southeast Brazil. Journal of Applied Entomology, v.118, p.437-441, 1994.

FERNANDES, W.D.; FERRAZ, J.M.G.; FERRACINI, V.L.; HABIB, M.E.M. Deterrência alimentar e toxidez de extratos vegetais em adultos de Anthonomus grandis Boh. (Coleoptera: Curculionidae). Anais da Sociedade Entomológica do Brasil, v.25, p.553-556, 1996.

FUCHS, T.W.; ENGLAND, A. Winter habitat for over-wintering boll weevils as a component of an integrated pest management program. Southwestern Entomology, v.14, p.265-269, 1989.

GABRIEL, D.; NETTO, N.D.; NOVO, J.P.S. Estudos sobre o comportamento do bicudo do algodoeiro Anthonomus grandis Boheman, 1843 (Coleoptera: Curculionidae), em condições de campo. Anais da Sociedade Entomológica do Brasil, v.21, p.41-57, 1992.

GUERRA, A.A.; GARCIA, R.F.; BODEGAS, P.R.; DECOSS, M.E. The quiescent physiological status of boll weevils (Coleoptera: Curculionidae) during the non-cotton season in the tropical zone of Soconusco in Chiapas, Mexico. Journal of Economic Entomology, v.77, p.595-598, 1984.

GUTIERREZ, A.P.; DOS SANTOS, W.J.; PIZZAMIGLIO, M.A.; VILLACORTA, A.M.; ELLIS, C.K.; FERNANDES, C.A.P.; TUTIDA, I. Modelling the interaction of cotton and the cotton boll weevil (Anthonomus grandis) in Brazil. Journal of Applied Ecology, v.28, p.398-418, 1991.

HABIB, M.E.M.; FERNANDES, W.D. Anthonomus grandis Boheman (Curculionidae) já está na lavoura algodoeira do Brasil . Revista de Agricultura, v.58, p.74, 1983.

HABIB, M. E. M.; FERNANDES, W. D.; FAVARO JR., A.; ANDRADE, C. F. S. Eficiência do feromônio de agregação e inseticidas químicos no combate ao bicudo Anthonomus grandis Boheman, 1843 (Coleoptera, Curculionidae). Revista de Agricultura, v.59, p.239-251,1984.

JONES, R.W.; CATE, J.R.; HERNANDEZ, E.M.; NAVARRO, R.T. Hosts and seasonal activity of the boll weevil (Coleoptera: Curculionidae) in tropical and subtropical habitats of northeastern Mexico. Journal of Economic Entomology, v.85, p.74-82, 1992.

LLOYD, E.P. Ecologia do Bicudo do algodoeiro, In: BARBOSA, S.; LUKEFAHR, M.J.; BRAGA SOBRINHO, R.O. (Ed.) Bicudo do algodoeiro. Brasília: EMBRAPA, Depto. de Difusão de Tecnologia, 1986. p.135-144.

LLOYD, E.P.; TINGLE, F.C.; GASTON, R.T. Environmental stimuli inducing diapause in the boll weevil. Journal of Economic Entomology, v.60, p.99-102, 1967.

LLOYD, E.P.; MCKIBBEN G.H.; WITZ J.A.; HARTSTACK, A.W.; LOCKWOOD D.F.; KNIPLING, E.F.; LEGGETT, E.F.. Mass trapping for detection, suppression and integration with other suppression measures against the boll weevil. In: MITCHELL, E.R. (Ed.) Management of insects pests with semiochemicals: concepts and practice. New York: Plenum Press, 1981. p.191-228.

LUKEFAHR, M.J.; BARBOSA, S.; SOBRINHO, R.B. Plantas hospedeira do bicudo com referência especial à flora brasileira. In: BARBOSA, S.; LUKEFAHR, M.J.; SOBRINHO, R.O.B. (Ed.) Bicudo do algodoeiro. Brasília: EMBRAPA, Depto. de Difusão de Tecnologia, 1986. $314 p$.

MAFRA-NETO, A.; BAKER, T.C. Elevation of pheromone response threshold in almond males pre-exposed to pheromone spray. Physiological Entomology, v.21, p.217-222, 1996 
MITCHELL, P.M.; HUDDLESTON, P.M.; WILSON, N.M.; HARDEE, D.D. Boll weevils: Relationship between time of entry into diapause and time of emergence from over-wintering. Journal of Economic Entomology, v.66, p.1230-1231, 1973.

MORALES, L.P.P.; CENA, F.P.; MENDES NETO, S.F.; COSTA, F.; OLIVEIRA, T. Resistência de genótipos de algodoeiro a Anthonomus grandis Boh. Frankliniella sp. e Aphis gossypii Glover. Anais da Sociedade Entomológica do Brasil, v.26, p.93-98, 1997.

NORDLUND, D.A. Semio-chemicals: A review of the terminology. In: NORDLUND, D.A.; JONES, R.L. ; LEWIS, W.J. (Ed.) Semio-chemichals: their role in pest control. New York: John Wiley \& Sons, 1981. p.13-30.

PALMER, J.O.; CATE, J.R. Over-wintering survival of prereproductive and post-reproductive boll weevil (Coleoptera: Curculionidae) in Central Texas. Environment Entomology, v.21, p.117-120, 1992.

PIEROZZI JR., I. Análise e aplicabilidade no complexo ecológico de Anthonomus grandis Boheman, 1843 (Coleoptera, Curculionidae)", na Região de Campinas, SP". 1989. Tese (Doutorado) - Instituto de Biologia, Universidade Estadual de Campinas.

PIEROZZI JR., I.; HABIB, M.E.M. Proposta de análise de componentes básicos para um programa de MIP para algodoais infestados por Anthonomus grandis Boheman, 1843 (Col., Curculionidae), na região de Campinas, SP. Revista de Agricultura, v.67, p.253-269, 1992a.

PIEROZZI JR., I.; HABIB, M.E.M. Levantamento e análise da eficiência de fatores bióticos de mortalidade natural de Anthonomus grandis Boheman, 1843 (Coleoptera, Cuculionidae), na região de Campinas, SP. Revista da Academia Colombiana de Ciencia, v.70, p.423-431, 1992b.
PIEROZZI JR., I.; HABIB, M.E.M. Aspectos biológicos e de comportamento dos principais parasitos de Anthonomus grandis Boh. (Coleoptera, Curculionidae), em Campinas, SP. Anais da Sociedade Entomológica do Brasil, v.22, p.317-323, 1993a.

PIEROZZI JR., I.; HABIB, M.E.M. Identificação de fatores de mortalidade natural dos estágios imaturos de Anthonomus grandis Boh. (Coleoptera: Curculionidae), na região de Campinas, SP. Anais da Sociedade Entomológica do Brasil, v.22, p.325-332, 1993b.

RAMALHO, F.S. ; SILVA, J.R.B. Período de emergência e mortalidade natural do bicudo do algodão. Pesquisa Agropecuária Brasileira, v.28, p.1221-1231, 1993.

ROELOFS, W.L. Attractive and aggregating pheromones. In: NORDLUND, D.A.; JONES, R.L.; LEWIS, W.J. (Ed.) Semiochemicals: their role in pest control. New York: John Wiley \& Sons, 1981. p.215-238

SUMMY, K.R.; CATE, J.R.; BAR, D. Over-winter survival of boll weevil (Coleoptera: Curculionidae) in Southren Texas: Evidence and significance of reprodutive diapause. Journal of Economic Entomology, v.86, p.369-376, 1993.

TAUBER, M.J.; TAUBER, C.A.; MASAKI, S. Seasonal adaptation of insects. Oxford: University Press, 1986. 411p.

TUMLINSON, J.H.; HARDEE, D.D.; GUELDER, R.C.; THOMPSON, A.C.; HEDIN, P.A.; MINYARD, J.P. Sex pheromones produced by the male boll weevil: isolation, identification and synthesis. Science, v.166, p.1010, 1969.

WHITE, J.R.; RUMMEL, D. Re-emergence profile of overwintered boll weevils and entry into cotton. Environment Entomology, v.7, p.7-14, 1978.

Received February 18, 2000 